\title{
Surveillance on Corynespora Leaf Fall Disease: Incidence and Severity on Natural Rubber (Hevea brasiliensis) in Certain Hot Spots Areas in Kerala
}

\author{
S.K. Mushrif ${ }^{*}$, M.J. Manju ${ }^{2}$ and Jacob Mathew ${ }^{3}$ \\ ${ }^{1}$ Department of Plant Pathology, College of Horticulture, Kolar, Karnataka, India \\ ${ }^{2}$ KVK, Sirsi, Karnataka, India \\ ${ }^{3}$ R.R.I.I., Rubber Board, Kottayam, Kerala, India \\ *Corresponding author
}

\section{Keywords \\ Corynespora cassiicola, Hevea brasiliensis, Corynespora Leaf Fall (CLF) disease \\ Article Info \\ Accepted: \\ 20 June 2020 Available Online: 10 July 2020}

\section{A B S T R A C T}

Survey on corynespora leaf fall (CLF) disease was undertaken in the hot spot areas in Thodupuzha and Kothamangalam regions of Idukki and Ernakulam districts respectively in Kerala for 3 years from 2011 to 2013. During this survey two aspects were covered; the number of units infected in a given village which was expressed in per cent disease incidence and the disease severity that was expressed in Per cent Disease Index (PDI). The study revealed that in 2011, Nalpathu Acre of Neyassery village in Thodupuzha region registered maximum disease incidence (85\%) and PDI of 47.15. In Kothamangalam region, Varapetty and Kanjiravelli villages registered $100 \%$ disease incidence. In this region, maximum PDI (38.0) was observed in Pinavoorkudy. In 2012, the disease incidence was on rise as reflected by more number of units being infected in Nalpathu Acre (90\%) in Thodupuzha region while Kadavoor, Varapetty and Kanjiravelli villages of Kothamangalam region registered $100 \%$ disease incidence. However, there was a sharp decline in disease severity as maximum PDI (13.9) was registered in Nalpathu Acre whereas it was 22.5 in Varapetty village of Kothamangalam. In 2013, the disease incidence remained constant (90\%) in Nalpathu Acre. However, the other four villages in Todupuzha region showed increasing trend in disease incidence. The Kothamanagalam region gave almost same trend as that of 2012 . The disease severity too gave almost similar trend as that was noticed in 2012 . These two regions where the disease was prevalent are surrounded by forest which may be contributing to the disease development. The immature phase of most popular clone RRII 105 was very much prone to the disease while in other clones like PB 260, RRII 414 and RRII 430 the disease was negligible to less. The disease was severe mainly in February/March months and it was declining thereafter. The probable reason for the decline in disease 2012 and 2013 is immediate plant protection measures taken up by the growers. 


\section{Introduction}

Corynespora leaf fall (CLF) disease of rubber [Hevea brasiliensis (Willd. ex Adr. de Juss) Muell. Arg.) caused by Corynespora cassiicola (Berk \& Curt) Wei is prevalent in almost all rubber growing regions of the world (Jacob, 2006a). The disease is noticed during the refoliation period in the rubber plantations. The disease is more severe during refoliation, between December and April (Reshma et al., 2016). During the past two decades, the pathogen has caused extensive damage to rubber tree plantations and may become a potential limiting factor in rubber yield in Asia (Breton et al., 2000; Jacob 2006 b). Young leaves are extremely susceptible to the disease though the disease attacks leaves of all stages. Another peculiar characteristic of the pathogen is it produces various types of symptoms depending on the type of clone and the maturity status of the tree. Thus, the diversity in symptoms makes it difficult to diagnose and to come out with suitable control measures. The disease is observed to be more prominent and widely distributed since 1975 in Malaysia (Kamar, 1994). Several authors have reported the economic importance of the Corynespora disease. In Sri Lanka, the disease which appeared in a polybags nursery of the clone RRIC 103 in 1985 spread rapidly in all rubber growing regions of the island devastating nearly 4000 ha by 1989 . Consequently, the clone RRIC 103 was uprooted through an island-wide campaign. The clone RRIC 103 which was high yielding and otherwise very promising had to be withdrawn from the recommendation (Liyanage et al., 1989).

In India, CLF disease of $H$. brasiliensis has been originally reported as a minor disease affecting nursery plants (Ramakrishnan and Pillay, 1961). Later, sporadic incidence of Corynespora on mature trees was reported from Kodumon, Chittar, Shaliacary, Kaliyar and Cheruvally during 1969 to 1976 (George and Edathil, 1980). But, in late nineties, this disease assumed a severe form in Nettana area of Karnataka. In traditional rubber growing belt of Kerala state, the disease has not been noticed in severe form. However, very recently, a few plantations in some pockets were severely affected by this disease. As described earlier, since this disease once a minor, became severe in Nettana and spread rapidly assuming a very severe form, the present study was initiated to assess the incidence, spread and severity of the disease in the already reported hot spots areas in Kerala.

\section{Materials and Methods}

The study involving the survey on CLF disease was undertaken in two main localities viz., Thodupuzha and Kothamangalam regions Idukki and Ernakulam districts (Fig. 1) of Kerala state, India where the disease has been earlier noticed. The survey was conducted for 3 years from 2011to 2013 during the month of January and continued till April. A total of 128, 181 and 209 units were surveyed in the years 2011, 2012 and 2013 respectively in both regions. Typical symptoms of blighting, railway track, shothole, defoliated trees and other symptoms pertaining to this disease were taken into consideration while assessing the disease (Fig.2 to Fig.4). In addition, peculiar symptoms of raised spots (Fig.5) were noticed in RRII 400 series clones. During survey a total number of 25 plants of the existing clone in the particular plot were assessed for the estimation of disease incidence and severity (Manju et al., 2001). PDI of the selected unit was assessed on a 0-5 scale based on intensity of spotting, lesions and leaf fall. The scale used was, $0=$ no disease; $1=$ very light (up to five spots); $2=$ light (5-10 spots and 10-25\% leaf fall); 3 moderate (> 10 spots and 26-50\% leaf fall); $4=$ severe (large lesions and 51-75 
$\%$ leaf fall) and $5=$ very severe (large lesions and $>75 \%$ leaf fall). The Per cent Disease Index (PDI) was calculated using the formula of McKinney (1923). Based on the incidence and severity of the disease, a map showing the affected and non-affected plots in Nalpathu Acre of Neyassery village was prepared.

\section{Results and Discussion}

\section{CLF disease survey 2011}

From the data on CLF disease incidence (Table 1; Fig.6), it was noticed that in Thodupuzha region, the disease was very much prevalent in Nalpathu Acre of Neyassery village. Barring 1-2 units of mature RRII 105 plantation the disease incidence was as high as $85 \%$. In other locations of Thodupuzha region the disease incidence ranged from 0 to $20 \%$. In Kothamangalam region, maximum disease incidence of $100 \%$ was recorded in Varapetty and Kanjiravelli areas followed by, Pinavoorkudy (89\%), Neriamangalam (87 \%) and Kadavoor (83\%).

The data (Table 2) on disease severity (PDI) revealed that in Thodupuzha, the PDI was highest (47.15) in Nalpathu Acre of Neyassery village. In other villages, the PDI was less. The disease range was also found to be high in Nalpathu Acre of Neyassery village ranging from 0 to $75 \%$. In Kothamangalam, maximum PDI (38.00) was recorded from Pinavoorkudy area of Kothamangalam with PDI ranging from 0 to 90 . However, maximum PDI range of total 0 to 100 was noticed in Neriamangalam village. But, this PDI was observed in only one unit of this region.

The disease progress (Table 2; Fig. 7) indicated that the maximum PDI (47.15) was noticed in the month of February in Nalpathu Acre of Neyassery village of Thodupuzha region whereas it was 38.00 during March in
Pinavoorkudy region of Kothamangalam. No disease was observed in Mullapuram and Mission Kunnu villages of Thodupuzha region. Thereafter there was decline in the PDI in both the regions. This is perhaps attributed to the immediate application of fungicides in these regions. During the survey, it was noticed that Nalpathu Acre and Pinavoorkudy areas were surrounded by forest (Fig. 8). Perhaps, the forest may be serving as inoculum source or a congenial environment created at the vicinity of the forest area which influences the disease development.

The results (Table 3) on clone wise PDI across immature and mature phase showed that the disease was observed to be severe in the age group of 1 to 7 years old crop which is otherwise an immature phase of RRII 105 clone whereas the disease was found to be minimum or absent in mature crop of RRII 105. This could be due to early wintering in the mature phase of RRII 105. The 400 series clones RRII 414 and RRII 430 exhibited less PDI however very typical symptoms of raised spots were noticed on the leaves of these clones and with no to negligible leaf fall. No disease was observed in the clone PB 260.

\section{CLF disease survey 2012}

The results on disease incidence in 2012 (Table 4; Fig. 9) revealed that in Thodupuzha, the disease was again seemed to be prevalent in Nalpathu Acre of Neyassery village. The disease incidence was noticed to the tune of $90 \%$. However, in other locations of Thodupuzha, most of the surveyed units were found to be comparatively less infected with the disease. There was a sharp increase in the infection in these units compare to previous year and it ranged from 31 to $69 \%$. In Kothamangalam region, maximum disease incidence of $100 \%$ was recorded in Varapetty, Kadavoor and Kanjiravelli areas 
followed by Pinavoorkudy (91\%), Neriamangalam $(90 \%)$. The data revealed that the disease incidence was observed to be on the increasing trend both in Thodupuzha and Kothamangalam regions.

The data on disease severity (Table 5) revealed that in Thodupuzha, maximum PDI of 14.50 was recorded in Nalpathu Acre with PDI ranging from 0 to 30 . In other areas of Thodupuzha region, the disease was less with the PDI ranging from 0 to 10 . In Kothamangalam, the PDI ranged from 0 to 50. Varapetty village registered maximum PDI (22.50) with range of 10 to 50 followed by 19.40 of PDI with range of 5-30 in Kadavoor village. Interestingly, the PDI was found to be on decline in Pinavoorkudy area of Kothamangalam with maximum PDI of 9.11. The results indicated that the PDI was very less in 2012 than in 2011. The reduction in the PDI can be attributed to the immediate spraying of fungicides by the growers which might have led to the reduction in inoculum load.

From the results of CLF disease progress (Table 5; Fig. 10) it was seen that the maximum PDI (14.50) was noticed in the month of February and from there onwards the disease was on decline in Thodupuzha region. In Kothamangalam region, highest PDI (22.50) was registered in Varapetty village in February month and thereon the disease started declining. In pinavoorkudy and Kadavoor villages barring one or two units which recorded the PDI of almost 50, there was reduction in the PDI in February. Thereafter there was decline in the PDI in both the regions. This is mainly attributed to the immediate application of fungicides in these regions.

The data on clone wise PDI across immature and mature phase (Table 6) indicated that the immature phase of the clone RRII 105 was more prone to attack as overall the disease was maximum in immature phase of the clone RRII 105. The mature phase of the clone RRII 105 had PDI of only10 to 20 . The 400 series clones RRII 414 and RRII 430 exhibited very typical symptoms of raised spots on the leaves and the PDI ranged from 0 to 5 with no to negligible leaf fall. No disease was observed in the clone PB 260. It was also found from the data that the PDI was less and was on decline in the immature phase of RRII 105 in 2012 than in 2011.

\section{CLF disease survey 2013}

The CLF disease survey was continued in the same localities in order to monitor the disease behaviour for the year 2013.

From the data (Table 7; Fig. 11) it was noticed that the disease incidence remained more or less constant $(90 \%)$ in Nalpathu Acre of Neyassery village of Thodupuzha. On the other hand, the remaining locations of Thodupuzha displayed sharp increase in the disease incidence as more number of units was found to be infected compare to that in 2012 and it ranged from 68 to $83 \%$. However, in Kothamangalam region, the disease incidence gave more or less same picture as that of the year 2012 and it was ranged from 80 to $100 \%$. Yet again overall disease incidence was on the rise compare to last 2 years in Thodupuzha and Kothamangalam regions.

From the data on disease severity (Table 8 ) it was observed that in Thodupuzha, maximum PDI of 16.25 and 16.20 was recorded in Vannapuram and Nalpathu Acre respectively while in other places the PDI was very less. The disease severity in Thoduzha region ranged from 0-25 PDI. In Kothamangalam, Pinavoorkudy village recorded maximum PDI (15.37) while in other places the disease severity did not touch a PDI of 10 indicating 
decline in disease severity. The disease severity in Kothamangalam region ranged from 0 to 35 PDI. The results indicated that the disease severity was on sharp decline than what was noticed in 2011.

From the results of CLF disease progress (Table 8; Fig. 12) it was seen that the PDI was maximum (16.25) in the month of March in Vannapuram village and in Nalpathu Acre it was 16.20 in the month of February. However, the disease was very less and there was marginal increase in disease severity up to March and it declined in April month. In Kothamangalam region, highest PDI (15.37) was registered in Pinavoorkudy village in February and thereafter the disease severity was on decline. In pinavoorkudy and Kadavoor villages barring one or two units there was reduction in the PDI in February.
This drop in disease severity is attributed again to the timely and appropriate plant protection practices that have resulted in the decrease in disease.

The data on clone wise PDI across immature and mature phase (Table 9) indicated that the immature phase of the clone RRII 105 was more prone to attack as overall the disease was maximum in immature phase of the clone RRII 105. The mature phase of the clone RRII 105 had PDI of only10 to $20 \%$. The 400 series clones RRII 414 and RRII 430 exhibited very typical symptoms of raised spots on the leaves and the PDI ranged from 0 to $5 \%$ with no to negligible leaf fall. No disease was observed in the clone PB 260. It was also found from the data that the PDI was less and was on decline in the immature phase of RRII 105 in 2012 than in 2011.

Table.1 Area wise distribution of Corynespora leaf fall disease incidence-2011

\begin{tabular}{|l|l|c|c|c|}
\hline Place & Village & $\begin{array}{c}\text { No. of units } \\
\text { visited }\end{array}$ & $\begin{array}{c}\text { No. of units } \\
\text { infected }\end{array}$ & \% units infected \\
\hline \multirow{2}{*}{ Thodupuzha } & $\begin{array}{l}\text { Nalpathu acre, } \\
\text { Neyassery }\end{array}$ & 20 & 17 & 85 \\
\hline & Thommankuthu & 21 & 03 & 14 \\
\hline & Mullappuram & 06 & 0 & 0 \\
\hline & Mission kunnu & 5 & 0 & 0 \\
\hline & Vannapuram & 20 & 4 & 20 \\
\hline \multirow{2}{*}{ Kothamangalam } & Pinavoorkudy & 18 & 16 & 89 \\
\hline & Kadavoor & 12 & 10 & 83 \\
\cline { 2 - 5 } & Neriamangalam & 15 & 13 & 87 \\
\cline { 2 - 5 } & Varapetty & 03 & 03 & 100 \\
\hline & Kanjiravelli & 08 & 08 & 100 \\
\hline
\end{tabular}


Table. 2 Corynespora leaf fall disease severity progress - 2011

\begin{tabular}{|c|c|c|c|c|c|c|c|c|c|}
\hline \multirow[t]{3}{*}{ Place } & \multirow[t]{3}{*}{ Village } & \multicolumn{8}{|c|}{ Disease severity (PDI) in different months } \\
\hline & & \multicolumn{2}{|c|}{ January } & \multicolumn{2}{|c|}{ February } & \multicolumn{2}{|c|}{ March } & \multicolumn{2}{|c|}{ April } \\
\hline & & $\begin{array}{l}\text { Disease } \\
\text { severity }\end{array}$ & Range & $\begin{array}{c}\text { Disease } \\
\text { severity }\end{array}$ & Range & $\begin{array}{l}\text { Disease } \\
\text { severity }\end{array}$ & Range & $\begin{array}{l}\text { Disease } \\
\text { severity }\end{array}$ & Range \\
\hline \multirow[t]{6}{*}{ Thodupuzha } & $\begin{array}{l}\text { Nalpathu acre, } \\
\text { Neyassery }\end{array}$ & 35.60 & $0-60$ & 47.15 & $3-75$ & 29.25 & $5-50$ & 18.40 & $8-30$ \\
\hline & Thommankuthu & 0.00 & 0 & 2.52 & $0-3$ & 2.24 & $3-5$ & 1.52 & $5-10$ \\
\hline & Mullappuram & 0.00 & 0 & 0.00 & 0 & 0.00 & 0 & 0.00 & 0 \\
\hline & Mission Kunnu & 0.00 & 0 & 0.00 & 0 & 0.00 & 0 & 0.00 & 0 \\
\hline & Vannapuram & 2.40 & $0-5$ & 5.25 & $0-8$ & 7.55 & $0-10$ & 6.35 & $0-8$ \\
\hline & Mean & 7.60 & & 10.98 & & 7.81 & & 5.25 & \\
\hline \multirow{8}{*}{ Kothamangalam } & & 2650 & -70 & 3333 & $0-75$ & 3800 & OO_OA & 2706 & $0-50$ \\
\hline & Todowern & 20.50 & $0-10$ & 25.53 & $\begin{array}{c}0.13 \\
0-13\end{array}$ & 50.00 & $0-30$ & 21.00 & $0-50$ \\
\hline & Neriamangalam & 1318 & $0-80$ & 2360 & 000 & 2800 & $0-100$ & 2582 & 0.100 \\
\hline & Varanetty & 1667 & 050 & 22,67 & 260 & 27.67 & 070 & 5000 & - 100 \\
\hline & Kaniiravelli & & & & & & & 20.00 & $10-40$ \\
\hline & Kanjiraveil & 2.50 & $0-5$ & 0.50 & $2-8$ & 1.03 & $0-10$ & 0.15 & $0-10$ \\
\hline & Mean & 12.27 & & 18.37 & & 21.36 & & 16.69 & \\
\hline & Overall mean & 9.94 & & 14.68 & & 14.58 & & 10.97 & \\
\hline
\end{tabular}


Table.3 Clone wise Corynespora leaf fall disease severity-2011

\begin{tabular}{|l|c|c|}
\hline Clone & Disease severity (PDI) in immature and mature Rubber crop \\
\hline & Mmmature (1-7 years) & Mature (8 years and above) \\
\hline RRII 105 & $0-90$ & $0-10$ \\
\hline RRII 414 & $0-5$ & - \\
\hline RRII430 & $0-5$ & - \\
\hline PB 260 & 0 & 0 \\
\hline
\end{tabular}

Table.4 Area wise distribution of Corynespora leaf fall disease incidence -2012

\begin{tabular}{|c|c|c|c|c|}
\hline Place & Village & $\begin{array}{l}\text { No. of units } \\
\text { visited }\end{array}$ & $\begin{array}{l}\text { No. of units } \\
\text { infected }\end{array}$ & $\%$ units infected \\
\hline \multirow[t]{5}{*}{ Thodupuzha } & $\begin{array}{l}\text { Nalpathu acre, } \\
\text { Neyassery }\end{array}$ & 20 & 18 & 90 \\
\hline & Thommankuthu & 26 & 08 & 31 \\
\hline & Mullappuram & 10 & 06 & 60 \\
\hline & Mission Kunnu & 8 & 3 & 37 \\
\hline & Vannapuram & 26 & 18 & 69 \\
\hline \multirow[t]{5}{*}{ Kothamangalam } & Pinavoorkudy & 35 & 32 & 91 \\
\hline & Kadavoor & 15 & 15 & 100 \\
\hline & Neriamangalam & 21 & 19 & 90 \\
\hline & Varapetty & 10 & 10 & 100 \\
\hline & Kanjiravelli & 10 & 10 & 100 \\
\hline
\end{tabular}


Table.5 Corynespora leaf fall disease severity progress - 2012

\begin{tabular}{|c|c|c|c|c|c|c|c|c|c|}
\hline \multirow[t]{3}{*}{ Place } & \multirow[t]{3}{*}{ Village } & \multicolumn{8}{|c|}{ Disease severity (PDI) in different months } \\
\hline & & \multicolumn{2}{|c|}{ January } & \multicolumn{2}{|c|}{ February } & \multicolumn{2}{|c|}{ March } & \multicolumn{2}{|c|}{ April } \\
\hline & & $\begin{array}{l}\text { Disease } \\
\text { severity }\end{array}$ & Range & $\begin{array}{l}\text { Disease } \\
\text { severity }\end{array}$ & Range & $\begin{array}{l}\text { Disease } \\
\text { severity }\end{array}$ & Range & $\begin{array}{l}\text { Disease } \\
\text { severity }\end{array}$ & Range \\
\hline \multirow[t]{6}{*}{ Thodupuzha } & $\begin{array}{l}\text { Nalpathu acre, } \\
\text { Neyassery }\end{array}$ & 11.60 & $0-30$ & 14.50 & $3-30$ & 5.60 & $5-15$ & 3.70 & $3-10$ \\
\hline & Thommankuthu & 0.00 & 0 & 1.20 & $0-5$ & 0.72 & $0-3$ & 0.52 & $0-2$ \\
\hline & Mullappuram & 0.00 & 0 & 3.00 & $2-5$ & 1.80 & $0-3$ & 1.20 & $0-2$ \\
\hline & Mission Kunnu & 0.00 & 0 & 2.00 & $1-6$ & 1.88 & $0-3$ & 1.88 & $0-3$ \\
\hline & Vannapuram & 1.23 & $0-4$ & 1.38 & $0-6$ & 0.96 & $0-2$ & 0.77 & $0-2$ \\
\hline & Mean & 2.57 & & 4.42 & & 2.19 & & 1.61 & \\
\hline \multirow{7}{*}{ Kothamangalam } & Pinavoorkudy & 6.31 & $0-20$ & 9.11 & $3-25$ & 4.23 & $2-15$ & 4.06 & $2-15$ \\
\hline & Kadavoor & 11.20 & $0-30$ & 19.40 & $5-30$ & 14.40 & $3-20$ & 9.40 & $3-15$ \\
\hline & Neriamangalam & 6.76 & $1-25$ & 7.90 & $3-15$ & 4.62 & $2-10$ & 2.90 & $2-5$ \\
\hline & Varapetty & 9.10 & $10-15$ & 22.50 & $10-50$ & 12.20 & $5-30$ & 7.90 & $3-15$ \\
\hline & Kanjiravelli & 3.40 & $0-5$ & 4.10 & $5-8$ & 3.60 & $3-5$ & 2.90 & $2-5$ \\
\hline & Mean & 7.35 & & 12.60 & & 7.81 & & 5.43 & \\
\hline & Overall mean & 4.96 & & 8.51 & & 5.00 & & 3.52 & \\
\hline
\end{tabular}

Table.6 Clone wise Corynespora leaf fall disease severity-2012

\begin{tabular}{|l|c|c|}
\hline Clone & \multicolumn{2}{|c|}{ Disease severity (PDI) in immature and mature Rubber crop } \\
\hline & Immature (1-7years) & Mature (8 years and above) \\
\hline RRII 105 & $0-30$ & $\mathbf{1 0 - 2 0}$ \\
\hline RRII 414 & $0-5$ & - \\
\hline RRII430 & $0-5$ & - \\
\hline PB 260 & 0 & 0 \\
\hline
\end{tabular}


Table.7 Area wise distribution of Corynespora leaf fall disease incidence -2013

\begin{tabular}{|l|l|c|c|c|}
\hline Place & Village & $\begin{array}{l}\text { No. of units } \\
\text { visited }\end{array}$ & $\begin{array}{l}\text { No. of units } \\
\text { infected }\end{array}$ & \% infected \\
\hline \multirow{2}{*}{ Thodupuzha } & $\begin{array}{l}\text { Nalpathu acre, } \\
\text { Neyassery }\end{array}$ & 20 & 18 & 90 \\
\cline { 2 - 5 } & Thommankuthu & 31 & 26 & 83 \\
\hline & Mullappuram & 14 & 10 & 71 \\
\hline & Mission kunnu & 12 & 9 & 75 \\
\hline & Vannapuram & 28 & 19 & 68 \\
\hline \multirow{2}{*}{ Kothamangalam } & Pinavoorkudy & 35 & 32 & 91 \\
\hline & Kadavoor & 19 & 19 & 100 \\
\hline & Neriamangalam & 21 & 19 & 90 \\
\hline & Varapetty & 14 & 14 & 100 \\
\hline & Kanjiravelli & 15 & 12 & 80 \\
\hline
\end{tabular}


Table.8 Corynespora leaf fall disease severity progress - 2013

\begin{tabular}{|c|c|c|c|c|c|c|c|c|c|}
\hline \multirow[t]{3}{*}{ Place } & \multirow[t]{3}{*}{ Village } & \multicolumn{8}{|c|}{ Disease severity (PDI) in different months } \\
\hline & & \multicolumn{2}{|c|}{ January } & \multicolumn{2}{|c|}{ February } & \multicolumn{2}{|c|}{ March } & \multicolumn{2}{|c|}{ April } \\
\hline & & $\begin{array}{l}\text { Disease } \\
\text { severity }\end{array}$ & Range & $\begin{array}{r}\text { Disease } \\
\text { severity }\end{array}$ & Range & $\begin{array}{c}\text { Disease } \\
\text { severity }\end{array}$ & Range & $\begin{array}{r}\text { Disease } \\
\text { severity }\end{array}$ & Range \\
\hline \multirow[t]{6}{*}{ Thodupuzha } & $\begin{array}{l}\text { Nalpathu Acre, } \\
\text { Neyassery }\end{array}$ & 7.30 & $2-10$ & 16.20 & $15-20$ & 11.55 & $10-15$ & 7.40 & $2-15$ \\
\hline & Thommankuthu & 2.29 & $0-5$ & 4.06 & $0-8$ & 2.84 & $0-5$ & 2.58 & $0-5$ \\
\hline & Mullappuram & 1.07 & $0-2$ & 2.64 & $0-5$ & 2.79 & $0-5$ & 2.57 & $0-2$ \\
\hline & Mission Kunnu & 1.33 & 0-2 & 2.42 & $0-5$ & 2.67 & $0-5$ & 1.33 & 0-2 \\
\hline & Vannapuram & 7.57 & $0-15$ & 14.32 & $0-25$ & 16.25 & $0-25$ & 10.18 & $0-15$ \\
\hline & Mean & 3.91 & & 7.93 & & 7.22 & & 4.81 & \\
\hline \multirow{7}{*}{ Kothamangalam } & Pinavoorkudy & 12.51 & $0-25$ & 15.37 & $0-35$ & 14.09 & $0-25$ & 10.29 & $0-15$ \\
\hline & Kadavoor & 6.32 & 0-10 & 9.16 & $0-15$ & 7.53 & $0-5$ & 5.21 & $0-5$ \\
\hline & Neriamangalam & 3.19 & $0-8$ & 6.71 & $0-15$ & 2.76 & $0-5$ & 2.10 & $0-5$ \\
\hline & Varapetty & 7.50 & $0-20$ & 9.29 & $0-30$ & 6.79 & $0-15$ & 5.21 & $0-10$ \\
\hline & Kanjiravelli & 1.80 & $0-5$ & 4.60 & $0-10$ & 2.13 & $0-5$ & 1.67 & $0-5$ \\
\hline & Mean & 6.26 & & 9.03 & & 6.66 & & 4.90 & \\
\hline & Overall mean & 5.09 & & 8.48 & & 6.94 & & 4.85 & \\
\hline
\end{tabular}

Table.7 Clone wise Corynespora leaf fall disease severity-2013

\begin{tabular}{|l|c|c|}
\hline Clone & \multicolumn{2}{|c|}{ Disease severity (PDI) in immature and mature Rubber crop } \\
\hline & Immature (1-7years) & Mature (8 years and above) \\
\hline RRII 105 & $5-35$ & $\mathbf{2 - 1 0}$ \\
\hline RRII 414 & $0-2$ & - \\
\hline RRII430 & $0-2$ & - \\
\hline PB 260 & 0 & 0 \\
\hline
\end{tabular}


Fig. 1 Map showing the areas in Thodupuzha region of Idukki district and Kothamangalam region of Ernakulam district in Central Kerala affected Corynespora leaf fall (CLF) disease.

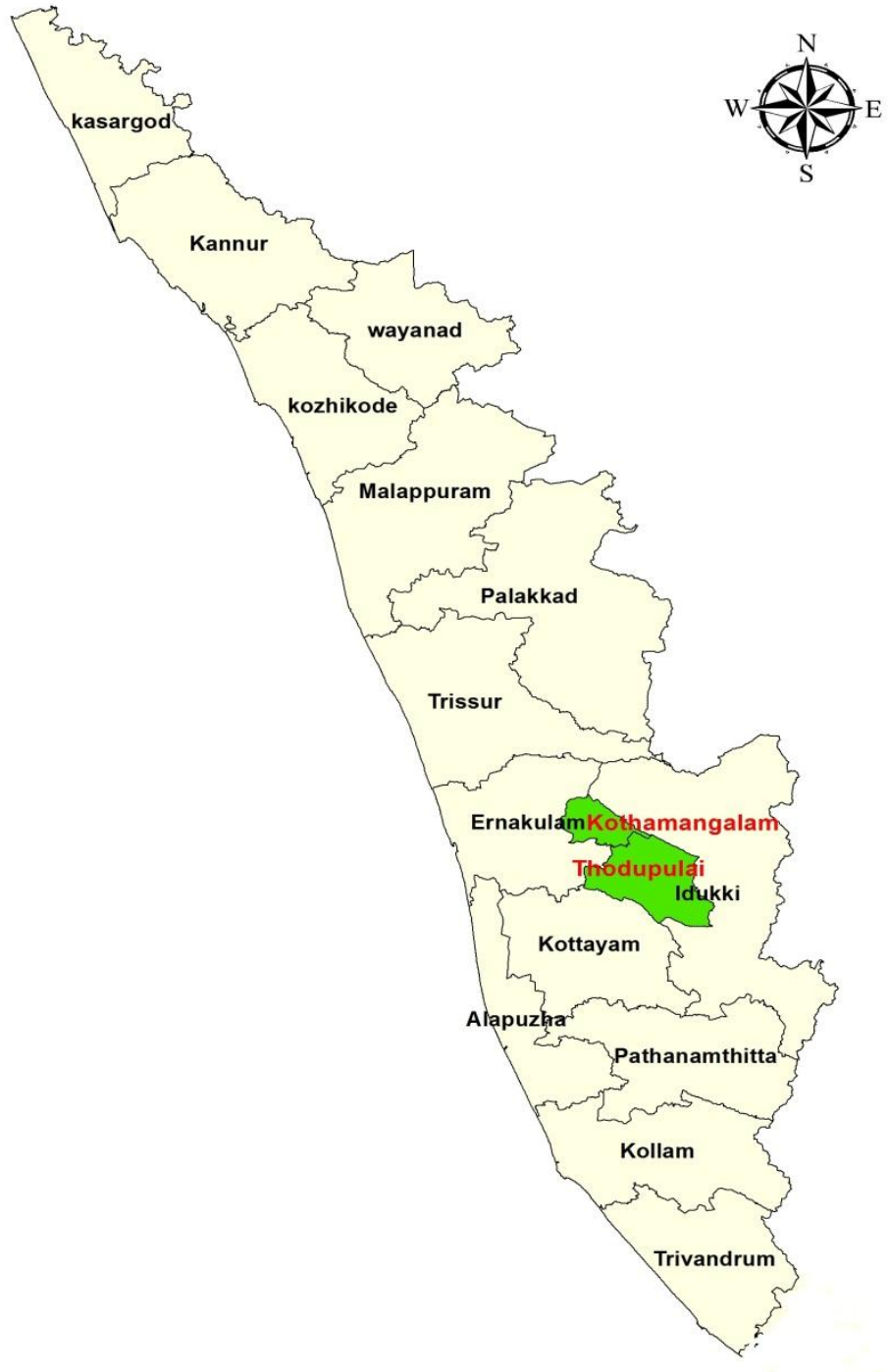


Fig.2 Blighted symptoms

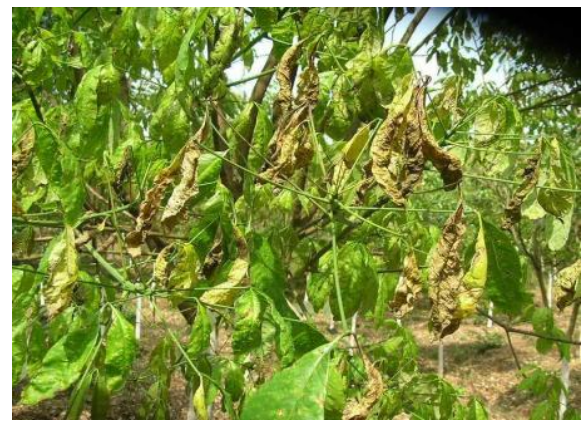

Fig.4 Railway track symptoms

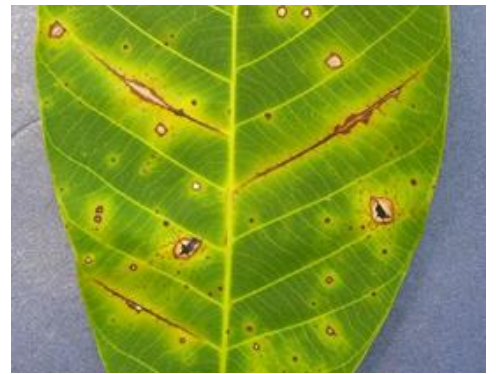

Fig.3 Severely affected plantation

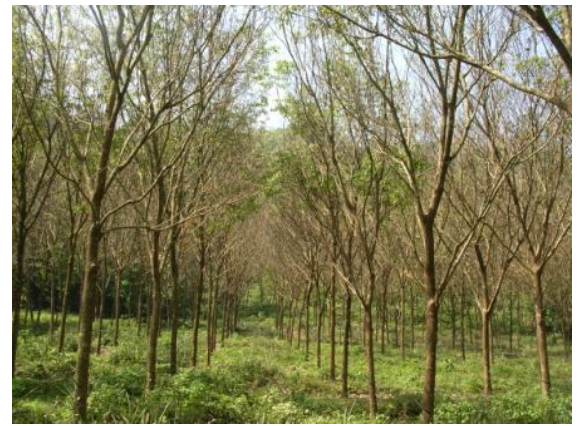

Fig.5 Raised spot symptoms

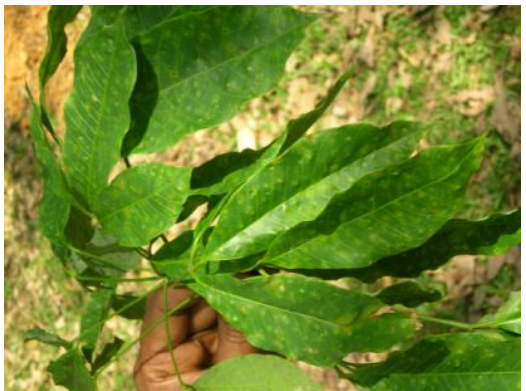

Fig.8 Map showing CLF disease affected region of Nalpathu Acre

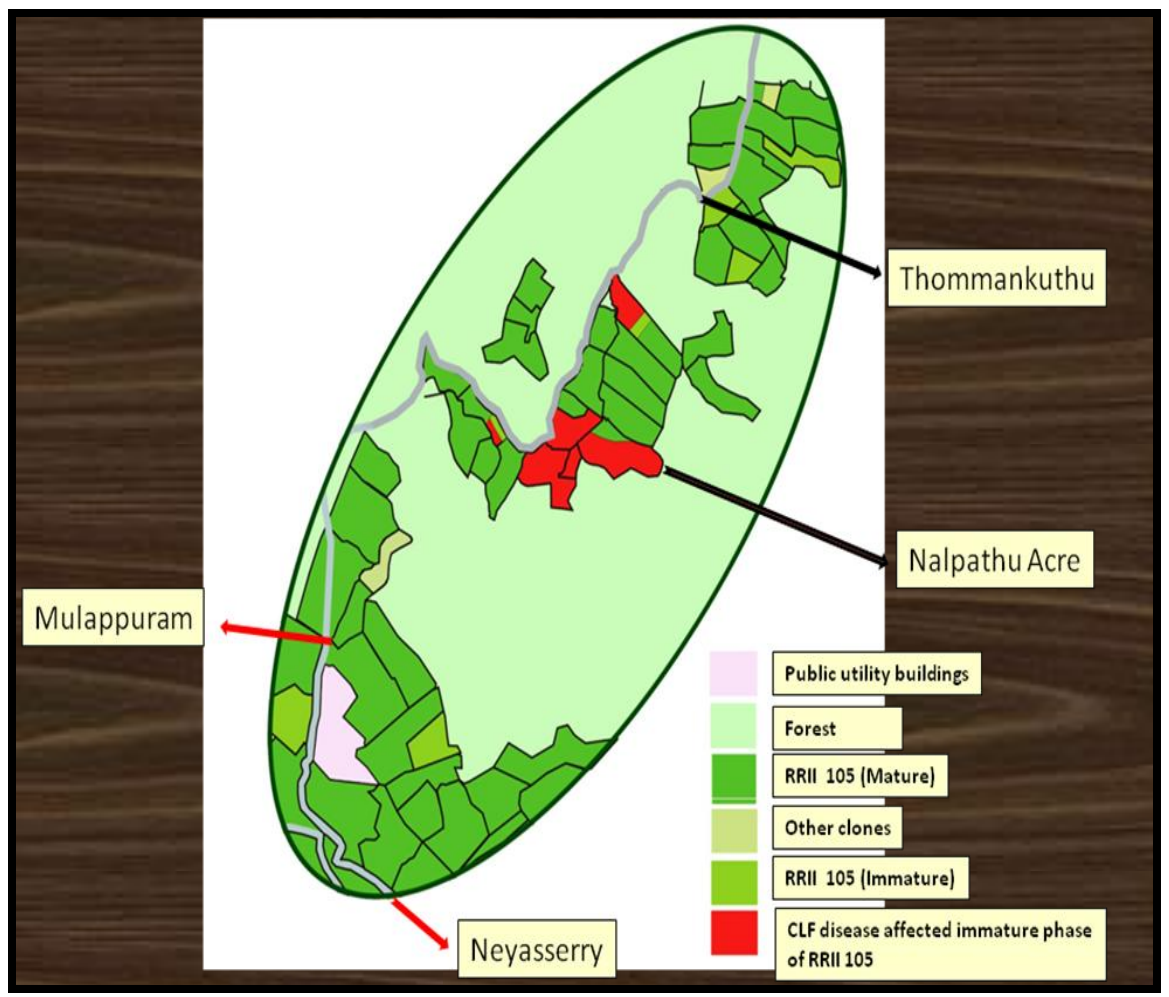


Fig.6 Area wise distribution of Corynespora leaf fall disease incidence -2011

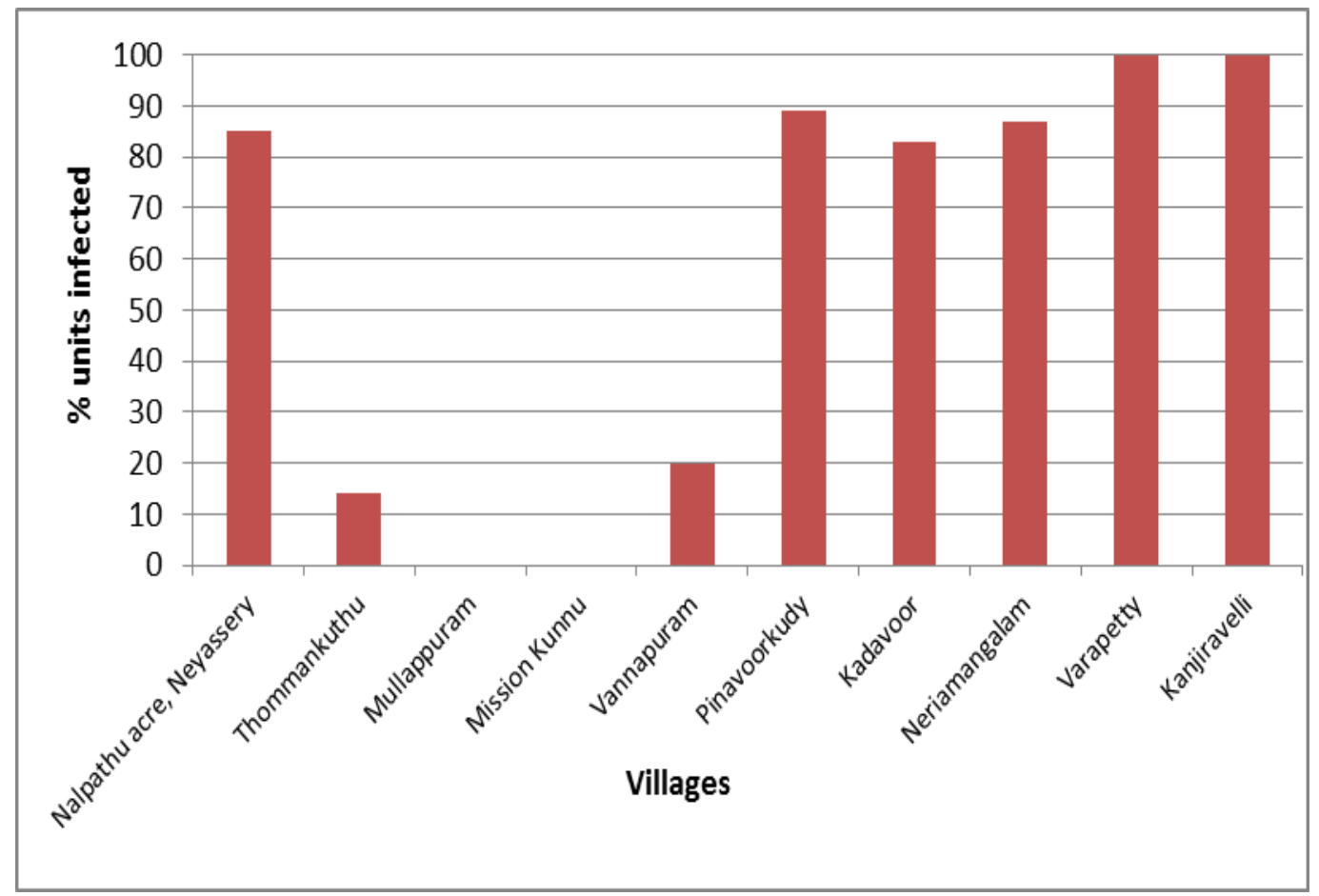

Fig.7 Corynespora leaf fall disease severity progress -2011

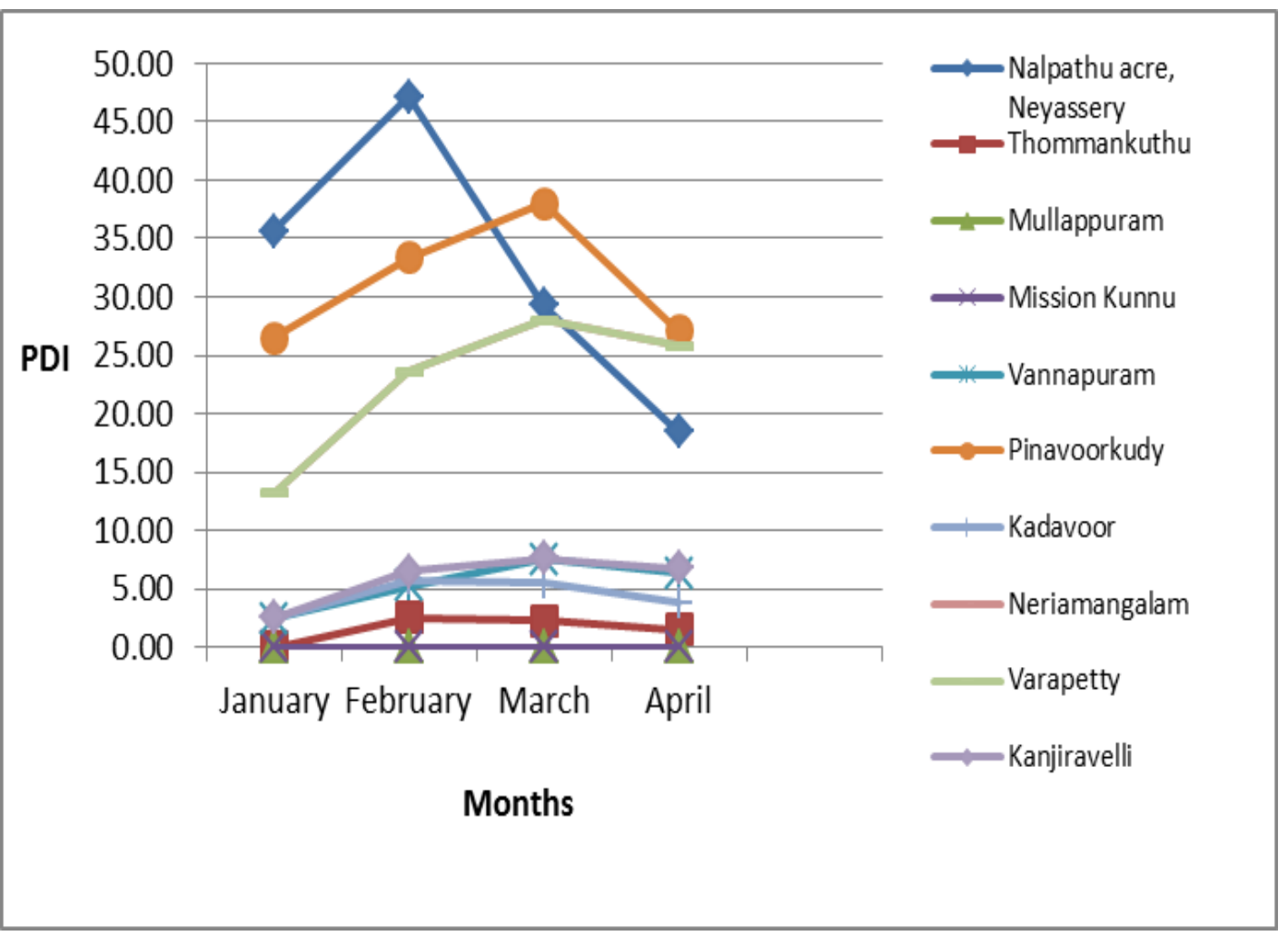


Fig.9 Area wise distribution of Corynespora leaf fall disease incidence -2012

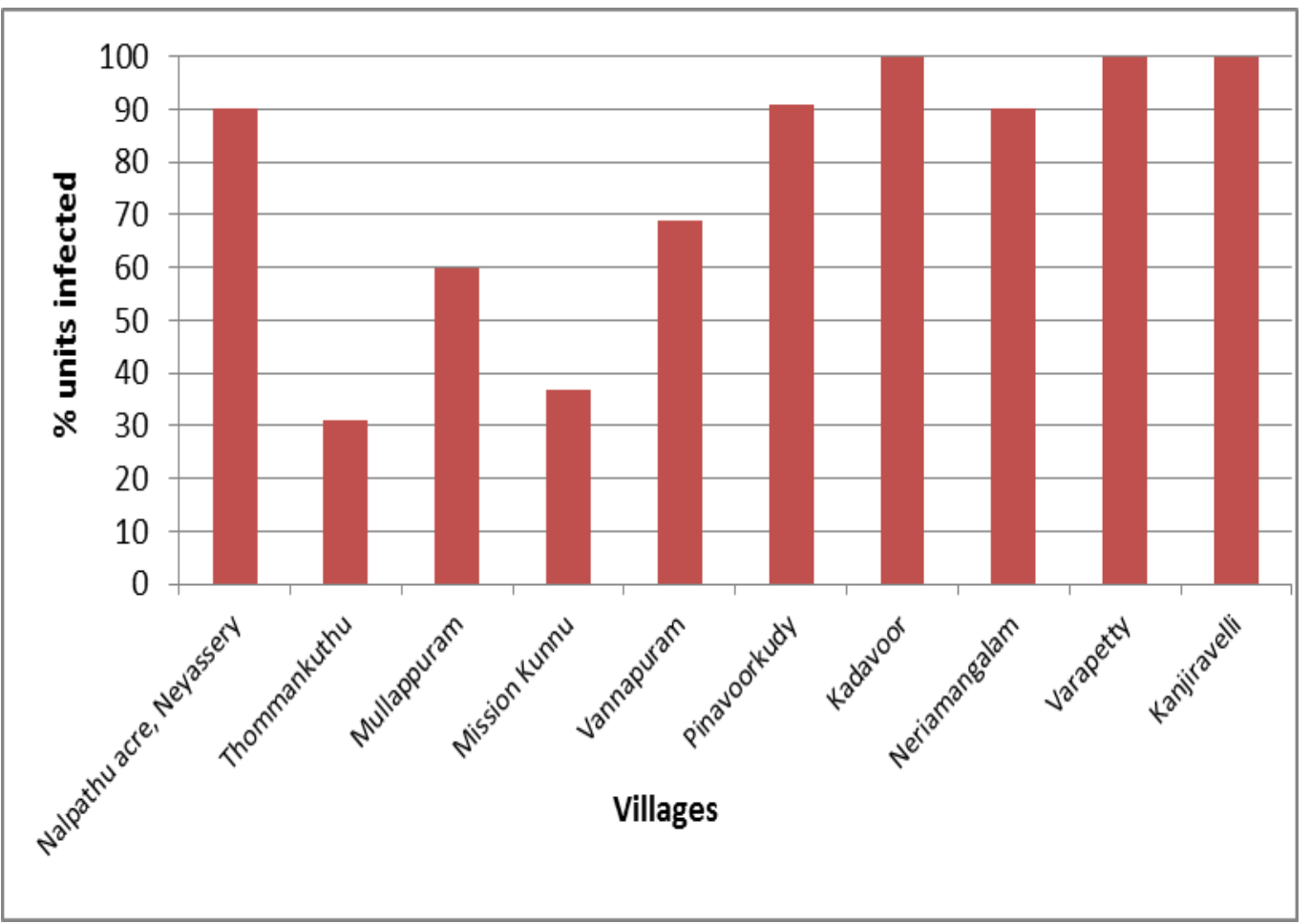

Fig.10 Corynespora leaf fall disease severity progress -2012

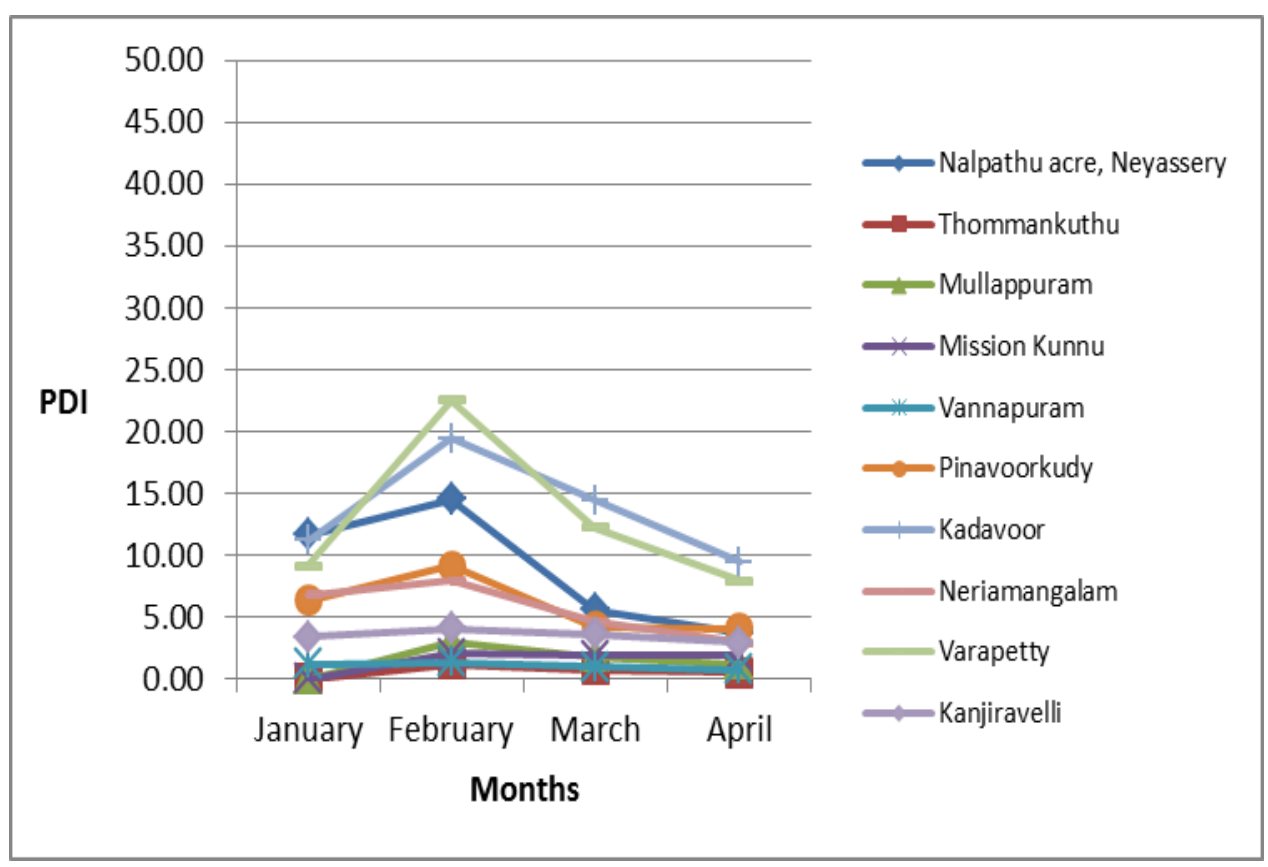


Fig.11 Area wise distribution of Corynespora leaf fall disease incidence -2012

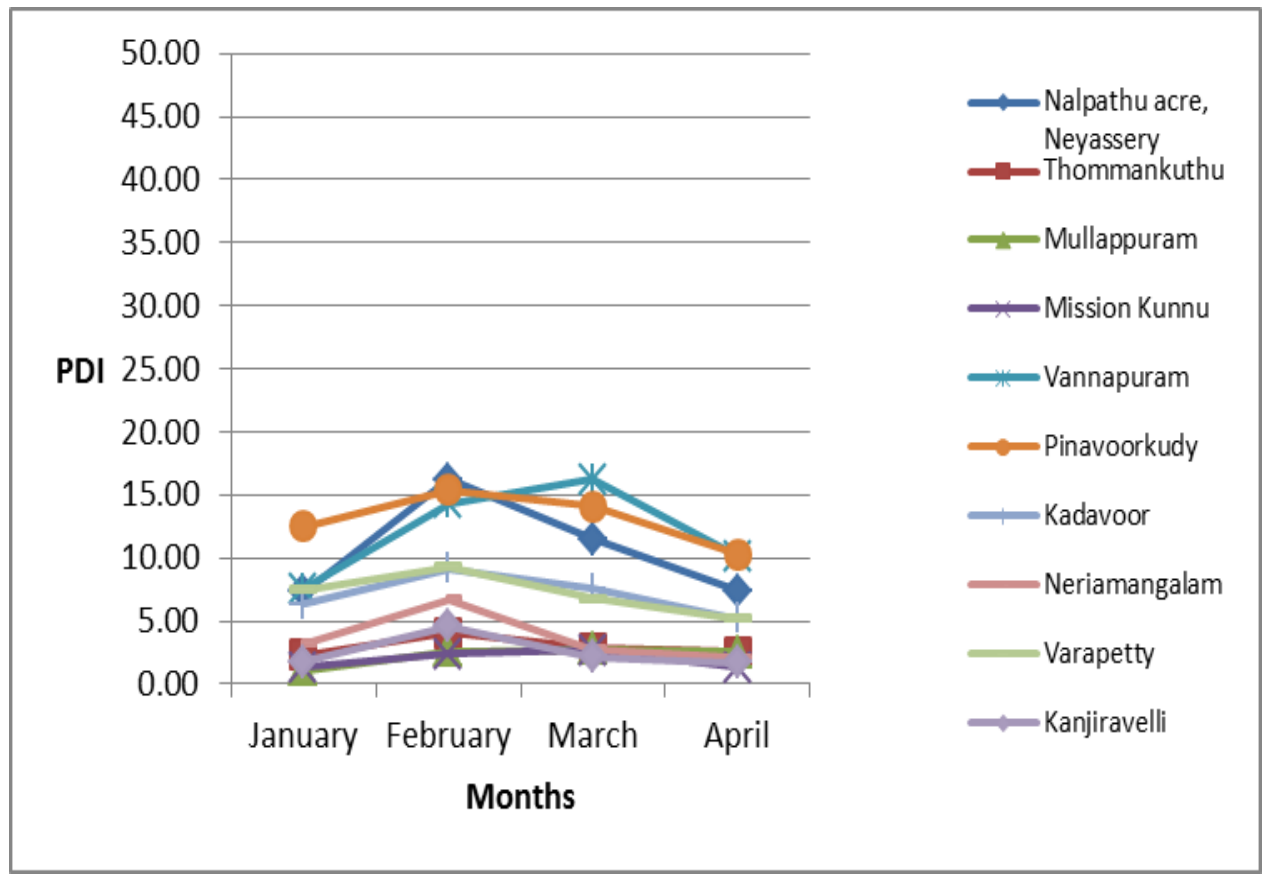

Fig.12 Corynespora leaf fall disease severity progress -2013

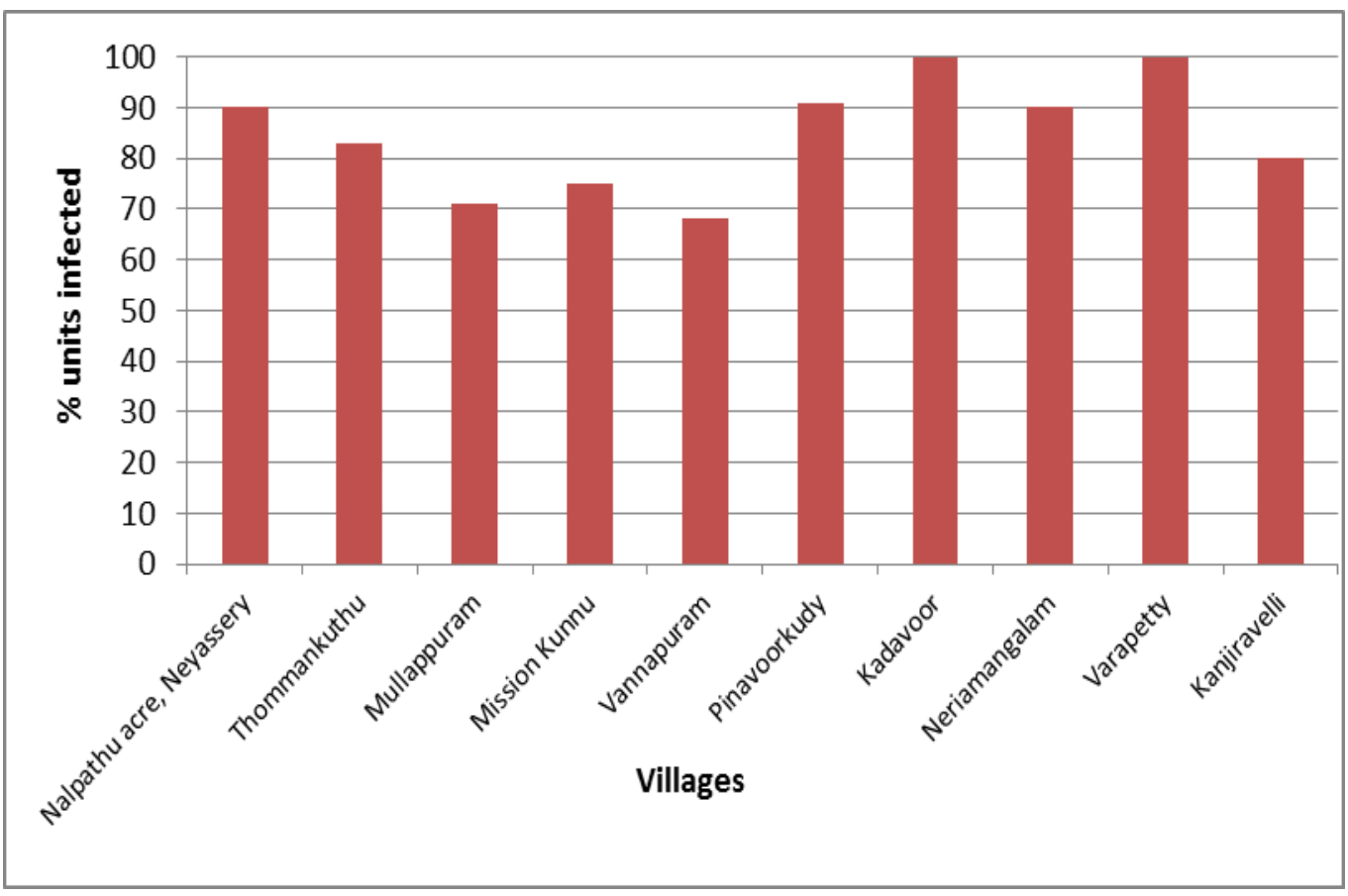


In the present study, the disease was noticed to be prominent in a few pockets of Idukki and Ernakulam districts of Kerala state. And these pockets were surrounded by forest.

The popular clone RRII 105 was found to be susceptible to the disease and the immature phase of this clone was very much prone to the disease attack. The studies on other clones revealed that the clones RRII 414, RRII 430 had negligible infection while the clone PB 260 was free from the disease. Manju et al., (2001) in his survey reported the clone RRII 105 to be susceptible to CLF disease while the clone PB 260 was moderately infected.

Similarly Kamar and Hidir (1996) reported that clones GT 1, PB 217, PB 235 and PB 260 were moderately infected. The disease occurs mainly in summer season as pathogen thrives well in conducive environment of sufficient light coupled with temperature of $28-30^{\circ} \mathrm{C}$. Water stress during refoliation period favours the infection rate (Chee, 1988).

Thus from these studies it is concluded that the disease was severe in Nalpathu Acre of Neyassery village and Pinavoorkuty in Kothamangalam region in 2011 and it was declined in 2012 and 2013 probably due to immediate plant protection measures taken up by the growers. The disease was noticeable in February/March and thereafter declined. The immature phase of the clone RRII 105 was more prone to the disease than the mature phase. The other clones studied were not affected much by the disease.

\section{Acknowledgment}

The authors are grateful to the Director of Research, Rubber Research Institute of India, Rubber Board, Kottayam, Kerala for providing all the assistance during this survey carried out for three years.

\section{References}

Breton, F., Sanier, C. and Auzac, J. 2000. Role of cassiicolin, a host-selective toxin, in pathogenicity of Corynespora cassiicola, causal agent of a leaf fall disease of Hevea. J. Rubber Res., 3 (2): 115-128.

George, M. K. and Edathil, T.T. 1980. A report on Corynespora leaf spot disease on mature rubber. Int. Rubber Conf., 1980, Kottayam, India.

Jacob, C.K. 2006a. Corynespora leaf disease of Hevea brasiliensis: A threat to natural rubber production. In: Corynespora leaf disease of Hevea brasiliensis: Strategies for management (Ed. C. Kuruvilla Jacob), Rubber Research Institute of India, Kottayam, pp. 9-16.

Jacob, C.K. 2006b. Symptoms of Corynespora leaf disease on rubber (Hevea brasiliensis). In: Corynespora leaf disease of Hevea brasiliensis: Strategies for management (Ed. C. Kuruvilla Jacob), Rubber Research Institute of India, Kottayam,pp.17-25.

Kamar, A.S.S. 1994. Distribution and disease severity of rubber diseases in Malaysia. Proceedings of the IRRDB symposium on diseases of Hevea,1994, Cochin, India, pp. 16-22.

Kamar, A.S.S. and Hidir, S.M. 1996. Current status of Corynespora leaf fall in Malaysia. Proceedings, Workshop on Corynespora Leaf Fall Disease of Hevea Rubber, 1996, Medan, Indonesia, pp. 21-28.

Liyanage, A.de S., Jayasinghe, C.K. and Liyanage, N.I.S. 1989. Losses due to Corynespora leaf fall disease and its eradication. Proceeding, Rubber Research Institute of Malaysia Rubber Grower's Conference, 1989, Malacca, Malaysia, pp. 401-410.

Manju, M.J., Idicula, S.P., Jacob, C.K., 
Vinod, K.K., Prem, E.E., Suryakumar, M. and Kothandaraman, R. 2001. Incidence and severity of Corynespora leaf fall disease of rubber in coastal Karnataka and North Malabar region of Kerala. Indian J. Nat. Rubber Res., 12(2): 134-141.

McKinney. 1923. Influence of soil temperature and moisture on the infection of wheat seedlings by Helminthosporium sativa. J. Agri. Res., 26: 196-217.
Ramakrishnan, T.S. and Pillay, P.N.R. 1961. Leaf spot of rubber caused by Corynespora cassiicola (Berk \& Curt) Wei. Rubber Board Bull., 5 (1): 32-35.

Reshma M, Philip, S., Rose, D., Joseph, A., Prem, E. and Joseph, J. 2016. Pathogenicity and toxin production of Corynespora cassiicola isolates causing Corynespora Leaf Fall Disease In Hevea brasiliensis Rubber Sci., 29(3): 277-285.

\section{How to cite this article:}

Mushrif, S.K., M.J. Manju and Jacob Mathew. 2020. Surveillance on Corynespora Leaf Fall Disease: Incidence and Severity on Natural Rubber (Hevea brasiliensis) in Certain Hot Spots Areas in Kerala. Int.J.Curr.Microbiol.App.Sci. 9(07): 2324-2340.

doi: https://doi.org/10.20546/ijcmas.2020.907.272 